\title{
Can Basal Neutrophil to Lymphocyte Ratio Predict the Clinical Outcome of Malign Melanoma Patients?
}

\section{Bazal Nötrofil Lenfosit Oranı Malign Melanom Hastalarında Sağkalımı Öngörebilir mi?}

\author{
Umut Varol $^{1}$, Gozde Kurttel ${ }^{2}$, İbrahim Vedat Bayoglu ${ }^{3}$, Ahmet Alacacioglu ${ }^{4}$, Ceyhun Varım ${ }^{3}$, Utku \\ Oflazoğlu ${ }^{4}$, Tarik Salman ${ }^{4}$, Yasar Yildiz ${ }^{4}$, Yuksel Kucukzeybek ${ }^{4}$, Mustafa Oktay Tarhan ${ }^{5}$ \\ ${ }^{1}$ İzmir Demokrasi Üniversitesi, Tıbbi Onkoloji Bilim Dalı, İzmir \\ ${ }^{2}$ İzmir Katip Çelebi Üniversitesi Atatürk Eğitim ve Araştırma Hastanesi, İç Hastalıkları Kliniği, İzmir \\ ${ }^{3}$ Sakarya Üniversitesi Eğitim ve Araştırma Hastanesi, Tıbbi Onkoloji Kliniği, İzmir \\ ${ }^{4}$ İzmir Katip Çelebi Üniversitesi Atatürk Eğitim ve Araştırma Hastanesi, T1bbi Onkoloji Kliniği, İzmir \\ ${ }^{5}$ İzmir Dokuz Eylül Üniversitesi Onkoloji Enstitüsü, İzmir
}

\begin{abstract}
ÖZET
GİRIŞ ve AMAÇ: Bağışıklık sistemi melanom hastalarının sağkalımında etkin bir rol oynamaktadır. Nötrofil lenfosit oranı (NLR) tümöre karşı etkin bağışıklık sisteminin indirek bir göstergesidir. Biz de çalışmamızda malign melanom hastalarında bazal NLR'nin prognostik önemini araştırmayı amaçladık.

YÖNTEM ve GEREÇLER: Sekiz yıllık dönemde tanı konmuş olan 134 malign melanom hastası retrospektif olarak değerlendirilmiş ve 94 hasta çalışmaya dahil edilmiştir. Tanı anındaki NLR değerleri incelenmiştir. ROC analizine göre eşik değer 2,1 olarak saptanmıştır ve bu değere göre hastalar yüksek veya düşük olarak sınıflandırılmıştır. NLR'nin prognostik açıdan hasta ve tümör karakteristikleri ile ilişkisi de araştııılmıştır.

BULGULAR: 94 hastanın 37'si metastatiktir ve 57 hasta adjuvan tedavi almıştır. Hastalardan NLR'si düşük olanların medyan sağkalımı 83,8 ay iken NLR'si yüksek olanların 23,8 aydır. ( $\mathrm{p}<0,001)$. Metastatik olmayan hastalardan NLR düşük grupta medyan sağkalıma ulaşılamazken NLR yüksek grupta medyan sağkalım 40,2 aydır ( $\mathrm{p}=0.031$ ), medyan hastalıksız sağkalım ise NLR düşük ve yüksek grupta sırasıyla 60,8 ay ve 14,4 aydır $(\mathrm{p}=0,038)$. Hasta yaşı $>60$ olanlarda NLR yüksekliği ile ilişki dışında $(p=0,027)$ NLR ile hasta ve tümör karakteristikleri arasında ilişki bulunamamıştır.
\end{abstract}

TARTIŞMA ve SONUÇ: Melanom hastalarında NLR yüksekliği kötü prognozla belirgin olarak ilişkili bulunmuştur ve prognoz için bir belirteç olarak kullanılabileceği görülmüştür.

Anahtar Kelimeler: Melanom, nötrofil, lenfosit, nötrofil lenfosit oranı, prognoz

\section{ABSTRACT}

INTRODUCTION: Immune system could play an effective role on clinical outcome of the melanoma patients. Neutrophil-to-lymphocyte ratio (NLR) is an indirect indicator for the immune response against to the tumor. So, we aimed to evaluate the prognostic importance of basal NLR in patients with malignant melanoma.

METHODS: We retrospectively reviewed 134 patients with malignant melanoma diagnosed in about an eight year period and 94 patients were included in the study. The values of NLR were assessed at the time of diagnosis. NLR cut-off value was determined as 2.1 by ROC curve. All patients were classified as high and low according to this cut-off value. The prognostic significance of NLR on clinical outcome of the patients was evaluated according to tumor or patient characteristics.

RESULTS: Among 94 patients, 37 were metastatic and 57 had received adjuvant therapy. For all cases, median overall survival (OS) was 83.8 months in NLR low group and 23.8 months in NLR high group ( $<<0.001)$. For nonmetastatic subgroup, median OS could not be reached in low NLR group and 40.2 months in high NLR group $(\mathrm{p}=0.031)$, median disease free survival were 60.8 months and 14.4 months $(\mathrm{p}=0.038)$ in NLR low and high group, respectively. There were no correlation between NLR and tumor or patient characteristics except of a higher NLR ratio was found in patients age $>60(\mathrm{p}=0.027)$.

DISCUSSION AND CONCLUSION: High NLR value showed a strong association with poor prognosis in melanoma patients and it can be used as a marker for prognosis.

Keywords: Melanoma, neutrophil, lymphocyte, neutrophil to lymphocyte ratio, prognosis 


\section{Introduction}

Melanoma is the most fatal type of skin cancer with aggressive clinical behavior and high propensity for lethal metastasis. Incidence and mortality rates of melanoma have been increasing in recent years (1). Early diagnosis is the most critical step in melanoma treatment. The prognosis and success of the treatment in advanced stage melanoma remains limited, despite the advances in immunotherapy and chemotherapy. Several prognostic factors, such as presence of ulceration, lymph node metastases, Clark level, and Breslow thickness have been identified in melanoma $(2,3)$.

Cancer-related inflammation is considered to be important in cancer prognosis and the mechanisms of inflammation that promote tumor progression and immune response suppression remain largely unknown (4-6). In recent years, many studies have been conducted to examine the relationships among biomarkers reflecting inflammation and inflammatory process in cancer. During inflammatory response, there are alterations in the ratio of circulating leukocytes. Physiological responses to inflammation by leukocytes lead to an increase in the number of neutrophils, concomitantly leading to a decrease in the number of lymphocytes, respectively. Studies have demonstrated that increase in neutrophil count and decrease in lymphocyte number is an independent prognostic factor for overall and progressionfree survival in many cancers $(7,8)$. Therefore, it is suggested that the ratio of these two subsets (neutrophil/lymphocyte: NLR) may be used as a simple marker of systemic inflammation and immune response $(9,10)$.

Immune system and its response to cancer effects prognosis of several malignant diseases especially the immunogenic ones. Renal cell carcinoma (RCC) and malignant melanoma are the first of these immunogenic cancers. The systemic inflammation-based basal NLR values which is a reflection of immune system were reported to be significance on prognosis of metastatic and non-metastatic RCC (11-13). Several studies have also shown the relationship between NLR and prognosis of many cancers, such as breast, colorectal, ovarian, bladder, gastric and pancreatic cancer (14-19).

NLR is a non-invasive marker which can be measured easily from the peripheral blood and there are limited data in the literature demonstrating the prognostic significance of NLR in malignant melanoma. In this study, we aimed to investigate the relationship between the basal NLR levels and progress of disease, and the prognostic value of the basal NLR in malignant melanoma patients.

\section{Materials and Methods \\ Study design}

Patients with malignant melanoma diagnosed in about an eight year period were retrospectively evaluated. Neutrophils and lymphocytes values of all patients were recorded at the time of diagnosis before any treatment. Age, gender, TNM staging, Clark level, ulceration and metastasis status of patients were recorded. Patients with chronic diseases such as diabetes mellitus, hypertension, ischemic heart disease, chronic obstructive pulmonary disease, renal and hepatic failure, history of a previous cerebrovascular event, infection, hematologic diseases, rheumatic diseases, or use of a drug which may cause increased in serum leukocyte and neutrophil values, were excluded from the study. Ninety-four patients meeting the appropriate criteria were included in the study. Treatment details and follow-up

All patients were evaluated in a multidisciplinary way. Non-metastatic highrisk patients (according to node involvement, Breslow thickness, and ulceration) received interferon-based therapy as an adjuvant treatment after surgery. Temozolomide or dacarbazine based treatments were administered as a first-line treatment for patients with metastatic melanoma. As immunotherapy or BRAF inhibitors were not allowed to use in the first line treatment of metastatic patients, they were used in the second or third line. Patients receiving adjuvant therapy were examined every 12 weeks for probable metastases risk, while patients with metastases were examined for a response after the third or fourth course of chemotherapy treatment. Interferon treatment as an adjuvant therapy was completed after one year in the patients without metastases and was then followed up.

\section{Response evaluation}

Response evaluation were assessed both during and after treatment using laboratory tests, including tests for hematological and biochemical parameters, as well as computed tomography (CT) or magnetic resonance 
imaging of the abdomen and pelvis and/or positron emission tomography CT. For the metastatic group, progression free survival (PFS) was defined as the time from the first day of treatment to the first day of documented progression or death. For patients who died without a known disease progression, we censored the PFS data at the time of their last follow-up. Overall survival (OS) has been calculated as the time from the diagnosis to patient death in both groups. Disease free survival (DFS) was calculated as time from the operation date to the time first local and/or distant recurrences were detected; or as the time last seen date in the patients without follow up. Statistics

Neutrophil to lymphocyte ratio was calculated retrospectively based on the hemograms at the time of diagnosis. The cut-off value of the calculated ratio was determined according to the ROC curve. Patients were divided into two groups (high and low) according to the cutoff value. Patients were classified based on tumor (T) size (T1-2 and T34) and lymph node (LN) involvement (LN negative and LN positive). The relationship between NLR and other prognostic factors, such as ulceration, tumor size, and tumor lymph node involvement, were examined separately in all patients. Quantitative data have been presented as means, medians, and ranges, while qualitative data are presented as frequencies and percentages. A chi-square test or Fisher's exact test was used to compare differences between the low NLR and high NLR groups. KaplanMeier method was used for survival analysis, and survival rates of groups were compared using the log-rank. The Cox proportional hazards regression model was used for comparison of NLR and tumor and patient characteristics. All statistical tests were twosided, and the level of statistical significance was set at 5\%. SPSS version 20.0 (SPSS Inc., Chicago, IL) was used for all statistical analyses.

\section{Results}

Of the 134 melanoma patients screened for this study, 94 met the inclusion criteria and were evaluated. Thirty-seven patients had metastases at the time of diagnosis and 57 patients had received adjuvant treatment after surgery. Majority of the patients $(54 \%)$ were female. The median patient age was 60 years, ranging from 18 to 94 . Nearly all patients had an ECOG PS of 0 or 1. General clinicopathologic characteristics of the patients have been listed in Table 1.

Table 1. Patients' characteristics

\begin{tabular}{|c|c|c|}
\hline Characteristics & Number (n) & $\%$ \\
\hline \multicolumn{3}{|l|}{ Gender } \\
\hline Female & 51 & 54 \\
\hline Male & 43 & 46 \\
\hline \multicolumn{3}{|l|}{ Age } \\
\hline$<60$ years & 45 & 48 \\
\hline$>60$ years & 49 & 52 \\
\hline \multicolumn{3}{|l|}{ Disease status } \\
\hline Metastatic group & 37 & 61 \\
\hline Non-metastatic group & 57 & 39 \\
\hline \multicolumn{3}{|l|}{ Primary tumor $(T)$} \\
\hline $\mathrm{T} 1$ & 7 & 7 \\
\hline $\mathrm{T} 2$ & 8 & 9 \\
\hline $\mathrm{T} 3$ & 18 & 19 \\
\hline $\mathrm{T} 4$ & 47 & 50 \\
\hline Unknown & 14 & 15 \\
\hline \multicolumn{3}{|l|}{ Pathology (N) } \\
\hline No & 37 & 39 \\
\hline N1 & 4 & 4 \\
\hline $\mathrm{N} 2$ & 6 & 7 \\
\hline N3 & 29 & 31 \\
\hline Unknown & 18 & 19 \\
\hline \multicolumn{3}{|l|}{ Ulceration } \\
\hline Yes & 40 & 43 \\
\hline No & 17 & 18 \\
\hline Unknown & 37 & 39 \\
\hline \multicolumn{3}{|l|}{ Clark level } \\
\hline 1 & 1 & 1 \\
\hline 2 & 2 & 2 \\
\hline 3 & 12 & 13 \\
\hline 4 & 30 & 32 \\
\hline 5 & 14 & 15 \\
\hline Unknown & 35 & 37 \\
\hline \multicolumn{3}{|l|}{ Exitus } \\
\hline Yes & 41 & 44 \\
\hline No & 53 & 56 \\
\hline \multicolumn{3}{|l|}{$N L R$} \\
\hline Low & 43 & 46 \\
\hline High & 51 & 54 \\
\hline
\end{tabular}

The NLR cut-off value was determined as 2.1 by ROC curve. All patients were classified as high and low using a NLR cut-off value of 2.1. The relationship between NLR and gender, tumor stage, lymph node involvement, and state 
of ulceration was examined with univariate analysis in all patients. NLR levels were found to be higher, approaching but not reaching the statistical significance limit in patients with T34 tumors and in lymph node positive patients at the time of diagnosis. In patients who underwent adjuvant treatment univariate analysis were performed to examine the relationship between NLR and gender, age $(<60$ and >60), tumor stage, lymph node involvement, metastasis/recurrence development, the status of ulceration, and mortality in follow-up. Higher NLR levels were found statistically higher in patients older than 60 years. Also, NLR levels were found to be higher, approaching but not reaching the statistical significance limit, in patients with T34 tumors in adjuvant treatment group (Table 2).

Table 2. Relationship between NLR and patient/tumor characteristics in non-metastatic melanoma patients

\begin{tabular}{|c|c|c|c|c|}
\hline \multirow{2}{*}{ Characteristics } & \multicolumn{4}{|c|}{ NLR } \\
\hline & $\begin{array}{c}\text { Low } \\
\text { (n) }\end{array}$ & $\begin{array}{l}\text { High } \\
\text { (n) }\end{array}$ & $\begin{array}{l}\text { All } \\
(\mathbf{n})\end{array}$ & p \\
\hline \multicolumn{5}{|l|}{ Gender } \\
\hline Female & 21 & 18 & 39 & \multirow{2}{*}{0.520} \\
\hline Male & 9 & 11 & 20 & \\
\hline \multicolumn{5}{|l|}{ Age } \\
\hline$<60$ years & 19 & 10 & 29 & \multirow{2}{*}{0.02} \\
\hline$>60$ years & 11 & 19 & 30 & \\
\hline \multicolumn{5}{|l|}{ Primary tumor $(T)$} \\
\hline $\mathrm{T} 1 / \mathrm{T} 2$ & 10 & 4 & 15 & \multirow{2}{*}{0.078} \\
\hline $\mathrm{T} 3 / \mathrm{T} 4$ & 20 & 25 & 65 & \\
\hline \multicolumn{5}{|l|}{ Pathology (N) } \\
\hline $\mathrm{N}(-)$ & 21 & 16 & 37 & \multirow{2}{*}{0.239} \\
\hline $\mathrm{N}(+)$ & 9 & 13 & 39 & \\
\hline \multicolumn{5}{|l|}{ Ulceration } \\
\hline Yes & 16 & 17 & 33 & \multirow{2}{*}{0.918} \\
\hline No & 8 & 7 & 15 & \\
\hline \multicolumn{5}{|l|}{$\begin{array}{l}\text { Metastatis in } \\
\text { follow-up }\end{array}$} \\
\hline Metastasis (-) & 17 & 11 & 28 & \multirow{2}{*}{0.150} \\
\hline Metastasis (+) & 13 & 18 & 31 & \\
\hline
\end{tabular}

For all patients median OS were 35.5 months (\%95 CI 26.2 - 44.7). The effect of NLR on OS was investigated in all patients. OS was found to be 83.8 months (\%95 CI NA) in low NLR group and 23.8 months (\%95 CI 6.1 - 41.4) in high NLR group $(\mathrm{p}<0.001)$ (Table 3; Figure 1).
Table 3. Overall survival, disease-free survival and progression free survival of patients according to NLR

\begin{tabular}{|c|c|c|c|c|}
\hline & $\begin{array}{c}\text { All } \\
\text { patients }\end{array}$ & $\begin{array}{r}\text { NLR } \\
\text { high } \\
\end{array}$ & $\begin{array}{r}\text { NLR } \\
\text { low }\end{array}$ & $\mathbf{p}$ \\
\hline $\begin{array}{l}\text { Median } \\
\text { OS } \\
\text { (months) }\end{array}$ & 35.5 & 23.8 & 83.8 & $<0.001$ \\
\hline $\begin{array}{l}\text { Adjuvant } \\
\text { group }\end{array}$ & 82.8 & 40.2 & NA & 0.031 \\
\hline $\begin{array}{l}\text { Metastatic } \\
\text { group }\end{array}$ & 11.9 & 7.5 & 13.8 & $\mathbf{0 . 0 3 3}$ \\
\hline $\begin{array}{l}\text { Median } \\
\text { DFS } \\
\text { (months) }\end{array}$ & & & & \\
\hline $\begin{array}{l}\text { Adjuvant } \\
\text { group }\end{array}$ & 34.6 & 14.4 & 60.8 & 0.038 \\
\hline $\begin{array}{l}\text { Median } \\
\text { PFS } \\
\text { (months) }\end{array}$ & & & & \\
\hline $\begin{array}{l}\text { Metastatic } \\
\text { group }\end{array}$ & 5.3 & 4.1 & 7.6 & 0.132 \\
\hline
\end{tabular}

Median OS and DFS were 82.8 months (\%95 CL NA) and 34.6 months (95 $\mathrm{Cl} 27.2$-41.9) in the patients receiving adjuvant treatment, respectively. The effect of NLR on OS and DFS were investigated and median OS could not be reached in low NLR group and median OS was found 40.2 months (\%95 CI 28.6 - 51.9) in high NLR group ( $\mathrm{p}=0.031)$ (Table 3; Figure 2). Median DFS were 60.8 months (\%95 CI 0.9 120.8) and 14.4 months (\%95 CI 0.0 - 30.2) $(\mathrm{p}=0.038)$ in low NLR and high NLR group, respectively.

Median OS and PFS of patients who have metastasis at the time of diagnosis were 11.9 months (\%95 CI 9.1 - 14.7) and 5.3 months (\%95 CI 3.4 - 7.2), respectively. The relationship between NLR and median OS / PFS was examined in metastatic patients. Median OS were 13.8 months (\%95 CI 7.4 - 20.2) and 7.5 months (\%95CI 3.5 - 11.5) $(\mathrm{p}=0.033)$ (Table 3; Figure 3) and median PFS were 7.6 months (\%95CI 3.5 - 11.5) and 4.1 months (\%95CI 3.5 - 11.5) in NLR low and high group, respectively. Although, median PFS was found to be longer in the patients with low NLR, this 
difference was not statistically significant $(\mathrm{p}=0.132)$.

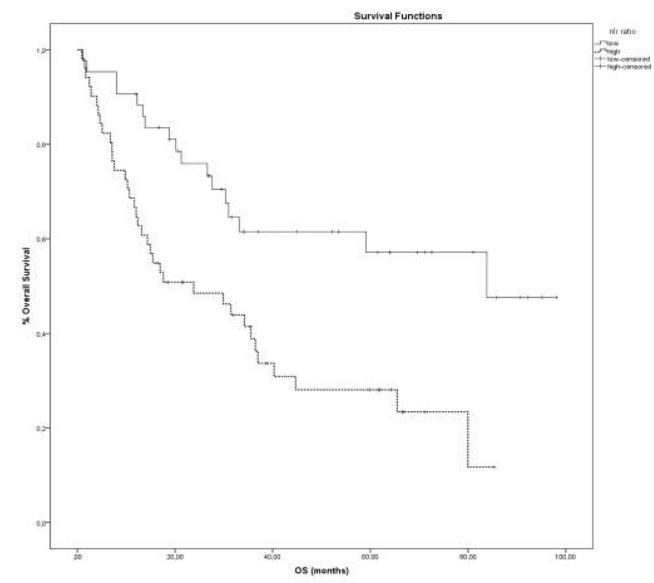

Figure 1. Overall survival curves of all patients stratified by NLR

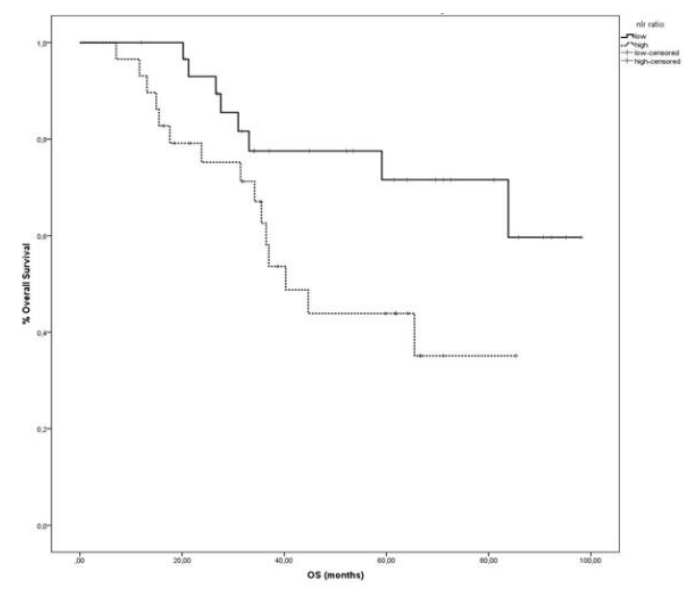

Figure 2. Overall survival curves of nonmetastatic patients stratified by NLR

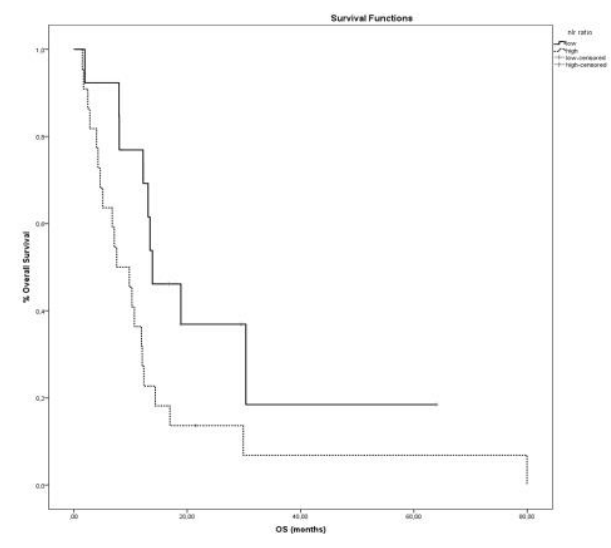

Figure 3. Overall survival curves of metastatic patients stratified by NLR

\section{Discussion}

In this study, we found that pretreatment high NLR was an effective worse prognostic factor both for OS and DFS in patients who received adjuvant therapy and for OS in metastatic patients with melanoma. Like Breslow thickness, nodal involvement and ulceration which have a major role on melanoma prognosis, our data have showed that NLR was an independent, statistically significant, prognostic factor for melanoma patients.

A recent study conducted by Fang et al. has shown $\mathrm{C}$ - reactive protein, which is a marker for inflammation, may be used as an indicator for melanoma progression (20). Similarly, high level of NLR has been demonstrated as a marker for inflammation. The main factors in the increase of NLR during inflammation are an increase in the neutrophil count and a relative decrease in lymphocyte count under inflammatory conditions. ${ }^{10}$ Neutrophils are main sources of growth factors, chemokines and proteases that stimulate angiogenesis, and these inflammatory cytokines may establish a tumor microenvironment and promote tumor development and progression $(21,22)$. Furthermore, an elevated neutrophil count may lead to inhibition of natural killer cells and activated $\mathrm{T}$ cells so it may lead to immunosuppression (22-24).

Cancer development and progression is associated with dysregulation of molecular pathways in tumor cells, but it may also be affected by cross-talk with the immune response. Lymphocytes are the main cellular components of adaptive immune response against the tumor. The presence of $\mathrm{T}$ lymphocytes in a tumor is an indication of an immune response to the tumor (25). Donizy et al. has shown that patients with melanoma infiltrated by high lymphocytes have a better prognosis (26). An increase in lymphocytes in peripheral blood which take part in immune response naturally causes a decrease in NLR. From this point of view, low NLR levels may be considered an indirect indicator of the activation of the immune system.

Recently, one of the most important issues of oncologic researches has been the immune system and its relationship with cancer cells. Melanoma was one of the most important immune related malignancies, as spontaneous 
regressions have been noted to occur occasionally due to infiltration of the tumor by lymphocytes, so it has become a target for immunotherapy (27). Until recently, treatments such as adoptive transfer of activated effector cells, non-specific immune modulatory agents such as interleukin 2, and immunization of patients through the use of vaccines have been applied in melanoma treatment. New molecules that target the immune system have been defined and put into use. Anti cytotoxic Tlymphocyte antigen 4 and monoclonal antibodies against programmed death 1 and its ligand, which block the immune checkpoint, has changed the treatment of melanoma (28).

Higher NLR baseline values have been found to be associated with shorter survival in patients with gastric, breast, renal cell, and nonsmall cell lung cancer. ${ }^{11-19}$ Additionally, in the literature there are several studies that evaluated the prognostic role of NLR in melanoma patients (29-36). In a meta-analysis conducted by Ding et al. including a total of 12 studies showed that a high NLR was predictive of poor OS and PFS in patients with melanoma (35). Cananzi FC et al. has demonstrated that high NLR was associated with worse prognosis in operated melanoma patients in which NLR cut of value was 5 (29). In our study, the cut-off value was at 2.1 estimated by Roc curve. Previous studies were used a range of 2 - 5 in various cancers types for NLR values. Despite the different cut off values, similarly, baseline higher NLR values were found to be associated with shorter survival both in our study and also in other studies (29-36).

In presented study, higher NLR baseline values were found to be associated with poor clinical outcome in patients receiving adjuvant therapy and those with metastatic disease. In conclusion, despite being a retrospective analysis and its limited number of sample size our study clearly suggested that that baseline NLR values has a significant prognostic role, both for non-metastatic and metastatic melanoma patients. Further randomized trials with larger patient groups are essential to evaluate the prognostic role of NLR in every stage of patients with malignant melanoma.

\section{References:}

1. Siegel R, Ma J, Zou Z, Jemal A. Cancer statistics, 2014. CA Cancer J Clin. 2014;64:9-29.
2. Lee ML, Tomsu K, Von Eschen KB. Duration of survival for disseminated malignant melanoma: results of a meta-analysis. Melanoma Res. 2000;10:81-92.

3. Balch CM, Gershenwald JE, Soong SJ, et al. Final version of 2009 AJCC melanoma staging and classification. J Clin Oncol. 2009;27:6199-206.

4. Ownby HE, Roi LD, Isenberg RR, Brennan MJ. Peripheral lymphocyte and eosinophil counts as indicators of prognosis in primary breast cancer. Cancer. 1983;52:126-30.

5. Strieter RM, Burdick MD, Mestas J, et al. Cancer CXC chemokine networks and tumour angiogenesis. Eur $\mathbf{J}$ Cancer. 2006;42:768-78.

6. Coussens LM, Werb Z. Inflammation and cancer. Nature. 2002;420:860-67.

7. Marchioni M, Cindolo L, Autorino R, et al. High Neutrophil-to-lymphocyte Ratio as Prognostic Factor in Patients Affected by Upper Tract Urothelial Cancer: A Systematic Review and Metaanalysis. Clin Genitourin Cancer. 2017;15:343-49.

8. Ray-Coquard I, Cropet C, Van Glabbeke M, et al; European Organization for Research and Treatment of Cancer Soft Tissue and Bone Sarcoma Group. Lymphopenia as a prognostic factor for overall survival in advanced carcinomas, sarcomas, and lymphomas. Cancer Res. 2009;69:5383-91.

9. Mei Z, Shi L, Wang B, et al. Prognostic role of pretreatment blood neutrophil-to-lymphocyte ratio in advanced cancersurvivors: A systematic review and metaanalysis of 66 cohort studies. Cancer Treat Rev. 2017;58:1-13.

10. Guthrie GJ, Charles KA, Roxburgh CS, et al. The systemic inflammation-based neutrophil-lymphocyte ratio: experience in patients with cancer. Crit Rev Oncol Hematol. 2013;88:218-30.

11. Dirican A, Kucukzeybek Y, Erten C, et al. Prognostic and predictive value of hematologic parameters in patients with metastatic renal cell carcinoma: second line sunitinib treatment following IFN-alpha. Asian Pac J Cancer Prev. 2013;14:2101-05.

12. Pichler M, Hutterer GC, Stoeckigt C, et al. Validation of the pre-treatment neutrophil-lymphocyte ratio as a prognostic factor in a large European cohort of renal cell carcinoma patients. Br J Cancer. 2013108: 901-7.

13. Keizman D, Ish-Shalom M, Huang P, et al. The association of pre-treatment neutrophil to lymphocyte ratio with response rate, progression free survival and overall survival of patients treated with sunitinib for metastatic renal cell carcinoma. Eur J Cancer. 2012;48:202-8.

14. Azab B, Bhatt VR, Phookan J, et al. Usefulness of the neutrophil-to-lymphocyte ratio in predicting short- and long-term mortality in breast cancer patients. Ann Surg Oncol. 2012;19:217-24.

15. Mano R, Baniel J, Shoshany O, et al. Neutrophil-tolymphocyte ratio predicts progression and recurrence of non-muscle-invasive bladder cancer. Urol Oncol. 2015;33:67.e1-7.

16. Lee DY, Hong SW, Chang YG, Lee WY, Lee B. Clinical significance of preoperative inflammatory parameters in gastric cancer patients. J Gastric Cancer. 2013;13:111-6.

17. Stotz M, Gerger A, Eisner F, et al. Increased neutrophil-lymphocyte ratio is a poor prognostic factor in patients with primary operable and inoperable pancreatic cancer. Br J Cancer. 2013;109:416-21. 
18. Li MX, Liu XM, Zhang XF, et al.Prognostic role of neutrophil-to-lymphocyte ratio in colorectal cancer: a systematic review and meta-analysis. Int $\mathbf{J}$ Cancer. 2014;134:2403-13.

19. Kim HS, Choi HY, Lee M, et al. Systemic Inflammatory Response Markers and CA-125 Levels in Ovarian Clear Cell Carcinoma: A Two Center Cohort Study. Cancer Res Treat. 2016;48:250-8.

20. Fang S, Wang Y, Sui D, et al. C-reactive protein as a marker of melanoma progression. J Clin Oncol. 2015; 33: 1389-96.

21. Shamamian P, Schwartz JD, Pocock BJ, et al. Activation of progelatinase A (MMP-2) by neutrophil elastase, cathepsin G, and proteinase-3: a role for inflammatory cells in tumor invasion and angiogenesis. J Cell Physiol. 2001;189:197-206.

22. Kusumanto YH, Dam WA, Hospers GA, Meijer $\mathrm{C}$, Mulder NH. Platelets and granulocytes, in particular the neutrophils, form important compartments for circulating vascular endothelial growth factor. Angiogenesis. 2003;6:283-7.

23. Shau HY, Golub SH. Inhibition of lymphokineactivated killer- and natural killer-mediated cytotoxicities by neutrophils. J Immunol. 1989;143:1066-72.

24. Di Carlo E, Forni G, Musiani P. Neutrophils in the antitumoral immune response. Chem Immunol Allergy. 2003;83:182-203.

25. Ohtani

$\mathrm{H}$.

Focus on TILs: prognostic significance of tumor

infiltrating lymphocytes in human colorectal cancer. Cancer Immun. 2007;7:4.

26. Donizy P, Kaczorowski M, Halon A, Leskiewicz M, Kozyra C, et al. Paucity of tumor-infiltrating lymphocytes is an unfavorable prognosticator and predicts lymph node metastases in cutaneous melanoma patients. Anticancer Res. 2015;35:351-8.

27. Minowa T, Kato J, Hida T, et al. Prognostic role of neutrophil to lymphocyte ratio in advanced melanoma treated with anti-programmed death1 therapy. J Dermatol 2018;45:e250-e251.
28. Fujisawa Y, Yoshino K, Otsuka A, et al. Baseline neutrophil to lymphocyte ratio combined with serum lactate dehydrogenase level associated with outcome of nivolumab immunotherapy in a Japanese advanced melanomapopulation.

$\mathrm{Br}$

Dermatol. 2018;179:213-5.

29. Cananzi FC, Dalgleish A, Mudan S. Surgical management of intraabdominal metastases from melanoma: role of the neutrophil to lymphocyte ratio as a potential prognostic factor. World J Surg. 2014;38:154250.

30. Lino-Silva LS, Salcedo-Hernández RA, García-Pérez L, Meneses-García A, Zepeda-Najar C. Basal neutrophilto-lymphocyte ratio is associated with overall survival in melanoma. Melanoma Res. 2017;27:140-4.

31. Davis JL, Langan RC, Panageas KS, et al. Elevated Blood Neutrophil-to-Lymphocyte Ratio: A Readily Available Biomarker Associated with Death due to Disease in High Risk Nonmetastatic Melanoma. Ann Surg Oncol. 2017;24:1989-96.

32. Finon A, Zaragoza J, Maillard $\mathrm{H}$, et al. A high neutrophil to lymphocyte ratio prior to BRAF inhibitor treatment is a predictor of poor progression-free survival in patients with metastatic melanoma. Eur $\mathrm{J}$ Dermatol. 2018;28:38-43.

33. Ma J, Kuzman J, Ray A, et al. Neutrophil-tolymphocyte Ratio (NLR) as a predictor for recurrence in patients with stage III melanoma. Sci Rep. 2018;8:4044.

34. Zhan H, Ma JY, Jian QC. Prognostic significance of pretreatment neutrophil-to-lymphocyte ratio

in melanoma patients: A meta-analysis. Clin Chim Acta. 2018;484:136-40.

35. Ding Y, Zhang S, Qiao J. Prognostic value of neutrophil-to-lymphocyte ratio in melanoma: Evidence from a PRISMA-compliant meta-analysis. Medicine (Baltimore). 2018;97:e11446.

36. Kanatsios S, Melanoma Project M, Li Wai Suen CSN, Cebon JS, Gyorki DE. Neutrophil to lymphocyte ratio is an independent predictor of outcome for patients undergoing definitive resection for stage IV melanoma. J Surg Oncol. 2018;118:915-921. 